\title{
Origin and evolution of the Emergency Service of the Hospital de la Santa Creu i Sant Pau (1967 to 1986)
}

\begin{abstract}
This paper aims to present the origin and evolution of hospital emergency services through the Emergency Service of the Hospital de la Santa Creu i Sant Pau de Barcelona, as it is the centre that has best preserved information about its own process, its evolution as a hospital and its adaptation to social change.

A very particular characteristic of this hospital is that it managed to integrate its users as part of the management board at a time when the country was in the middle of a democratic transition after forty years under a dictatorship.

For the realization of this paper, we have used the qualitative methodology has been used, in particular, Heidegger's hermeneutical phenomenology, so as to triangulate documentary analysis with open interviews with relevant people about the historical process being studied, and to obtain the resulting document. A descriptive work, with a completely objective, historical account.

The existence of this article cannot be explained without considering the importance of certain documentary sources that remain, so far, largely unexplored, such as the archives of the neighbourhood associations of Barcelona and the impact of social movements in achieving the creation of new health services, their maintenance and surveillance, and the promotion of their development according to the needs of each historical moment. That would be the main conclusion.
\end{abstract}

Keywords: Hospital Emergency Services; Hospital Evolution; Social Movements

Corresponding author: e-mail: carmevigi@gmail.com

Received 15 September 2020 - Accepted 20 November 2020

This is an Open Access article distributed under the terms of the Creative Commons Attribution-Non-Commercial-No Derivatives License (http://creativecommons.org/licenses/by-nc-nd/4.0/), which permits non-comercial re-use and distribution, provided the original work is properly cited, and is not altered or transformed in any way. 


\section{Introduction}

Once the World War II was over, between the 50s and especially during the 60s of the 20th century, most European countries started reforming healthcare to adapt to the social, economic and health-related changes that had taken place. Thus, most of them were building new hospitals or rebuilding those that could still continue to function. All these efforts were aimed at achieving healthcare reform; to make them more suited for the times to come ("Evolución de la organización Hospitalaria en los países de la C.E.E.”, Estudios sobre Hospitales, 1969, 38: 35-36; Sitjes 1962b)., ${ }^{1}$ It was understood that all around, there should be general university hospitals which contained all existing medical specializations, lower-grade hospitals with most specializations, and local hospitals with the capacity to serve most people in the region. All of them should have an Emergency Service. Changes of this kind were taking place in France, England, Ireland ("Los Hospitales en Irlanda." Estudios sobre Hospitales 1971, 48: 9), Switzerland, the USSR, Romania, Finland, Belgium and Portugal, among others (Alegre 1962a and 1962b; Artigas 1975 and 1976; Department of Health Edingburg 1963; Jaén 1964; Ramis and Torres 1973; Sitjes 1962; Torre 1964; Villamarín 1971).

Also during the $60 \mathrm{~s}$ - in parallel to what was happening in Europe - the United States and Canada began working on "the forgotten diseases of modern society"; not just traumatology related to work and traffic accidents, but also their numerous consequences and side effects, which exponentially increased the cases of disability in the civilian population. These trauma centres began to be developed in the United States in 1966. The traumatology services would

\footnotetext{
${ }^{1}$ Since the advent of the industrial revolution, accidents related to work injuries and new forms of transport had sharply risen, constituting a new epidemiologic context where it became commonplace for a physician to rutinely deal with medical and surgical emergencies.
} 
benefit from out-of-hospital care by adding specialized personnel to their teams (Evans 2007; Mulllins 1999; "La Situación Hospitalaria en las Américas” 1975 73: 42-57; Trunkey 2000). They would also manage to include other medical specializations, such as neurosurgery, that would help in the treatment and recovery of head trauma (Trunkey 2007). But both countries had a problem in common; the great extension of their territory, which made it necessary to regionalize their emergency services and trauma care in most of the large cities. This would be achieved in Canada in 1980 (Evans 2007), while in the United States it began in the 1970s. At the same time, the involvement of surgeons in the care of traumatic patients came to be considered necessary, since the increase in stab wounds and gunshot wounds with ruptured spleen and liver increased the mortality of these patients.

While regionalization was still spreading throughout the North of the United States until well into the 1980s (Beuran et al. 2011; Boyd 2010; Mehrotra et al. 2010; Phillips et al. 2005; Rockwood et al. 1976), on the other side of the world, in Japan, already the 60s, a law had been passed to implement emergency services in certain hospitals, which would be designated by the government, and which were put into operation without singular specializations, having doctors that were experts in the acutely ill be the ones in charge of emergencies (Hori 2010).

In the same decade - the 60s -, in Spain, this concern was also present, and it was then that a group of doctors, taking advantage of the fact that Spain was beginning to open up to the rest of the world, started traveling to other European cities to attend and participate in conferences and other events about hospitals, and bringing back the articles they found, later translating and publishing them in the journal Estudios sobre Hospitales y beneficencia, bringing their knowledge to the country. 
Thanks to this resource, we know that in Europe, at the time, each country's emergency services were being organized according to their specific needs and health policy. Thus, in the United Kingdom they created hospitals dedicated to emergency treatment and care, but in Scotland, it was recommended that district hospitals offer a service to tend to accidents 24 hours a day, and that it be staffed by an in-house physician (Departament of Health Edinburgh 1963; Stewart 2008). Meanwhile, in the USSR, the existing practitioner/midwife stations - of which there was one per every nine hundred people - were in charge of giving first aid to those who needed it, and referred the sick to the hospital when necessary (Jaén 1964). In Romania, emergencies that happened during the night, or during hours that the dispensary was out of service, were tended to in the first care unit that was part of the hospital. All general practitioners, specialists from the polyclinic, even from the hospital, had to go through this service (Ramis and Torres 1973). In Finland, in order to lower health costs, they first promoted primary care centres, where they included emergency care (Artigas 1976).

In Belgium, the emergency system was perhaps one of the most innovative; knowing that the immediate assistance of a patient or injured person on the public highway or at home was a great problem, the Belgian government had perfectly coordinated emergency resources, both in terms of transport and the facilities available for immediate assistance. This efficiently organized setup used a single phone number for the whole country (900) which everyone could call in case of emergency, and which provided information about the nearest ambulance centre available to the patient, and immediate access by the ambulance to the nearest health centre where the patient could be transferred. This way, at any time of the day or night, whoever needed it could be transferred to the facility that was best suited to treat them. This system was completed with legal regulations that guaranteed the economic coverage of the services 
provided in any centre. This coverage was laid out in such a way that, ultimately, in the case of a disadvantaged person, the financial responsibility for this assistance was directly entrusted to their municipality or the State (Artigas 1975).

In Portugal, the Ministry of Health and Social Assistance began its hospital organization in 1946, while in 1963 it drew up a health coordination program in which all the health services were integrated into the same functional plane, including emergency relief services. Additionally, it expanded its disaster relief program with the expressed awareness that it's proper functioning relied heavily on effective emergency response. A good example of this was the distribution of emergency services in the Lisbon area in 1963. The emergency care facilities were distributed in two regions so that the population volume was proportional to the number of beds. There were eight civil hospitals with a total of four thousand beds. Meanwhile, the specialized emergencies were distributed by areas. This assistance was completed by emergency aid stations within several hospitals, clinics and companies, as well as private medical and nursing facilities, which offered permanent care. The two most important hospitals had two different setups. While the Banco de Soccorro (emergency service) of the San José Hospital based their assistance mainly on their surgical team and was directed by a surgeon, the Hospital de Santa María was organized by services, co-directed by an internal medicine doctor and a surgeon. Its wards were reinforced by an analyst, an anaesthetist and a radiologist, demonstrating that a multi-headed approach was also very effective and not as supervisory as when it relied on a single person. This scheme was a recommendation of the Portuguese Ministry of Health to plan emergencies in the capital, but new emergency centers specialized in traumatic brain injuries and burns had yet to be opened, as well as the creation of mobile units for care at the scene of the accident (Aragó 1968; Torre 1963 and 1964). 
In France, in 1961, there were around 500,000 injuries a year, of which 200,000 were caused by accidents at work. Another similar figure was caused by accidents on public roads, while the remaining 100,000 were due to sports or due to home accidents. Because of this, in the Paris area, the Cochin hospital, a trauma centre attached to a general university hospital, had 200 beds, an emergency room, an orthopaedic service, a laboratory, a burned victims ward, and a radiology ward. It offered permanent care 24 hours a day, with a surgical team, a resuscitation room, laboratories, radiology, a cast room, etc. It was inside a general university hospital to facilitate access to other specializations related to accidents, such as neurology, orthopaedics, surgery, ophthalmology, maxillofacial surgery, urology, etc. It also had an outpatient service to be able to do a complete follow-up until the injured person was reintegrated into work. In the emergency service there was a treatment room, a cast room, operating rooms, radiology..., and short-stay hospital beds that were emptied daily. Its mission was to treat minor traumas and classify the injured according to the affected region in order to direct them to the corresponding department. This facility also had a septic department for infected cases that required isolation measures (Dunan 1974; Poirson-Sicre 2000; Sitjes 1962a).

But the concept that really led to the development of emergency services in the modern era was "cardiopulmonary resuscitation" (Safar, Escarraga and Elam), which did not appear until the early 1960s with the publication of mouth-to-mouth ventilation techniques developed by James O. Elam (1918-1995) and his collaborators in the 1950s (Elam 1977; Elam, Brown and Elder 1954), together with external cardiac compressions, the study of which corresponds to William B. Kouwenhoven (1886-1975) and collaborators, in 1960 (Kouwenhoven, Jude an Knickerbocker 1960). It was during this same time that the techniques for external cardiac defibrillation were perfected (Lown, Amarasingham and Neuman 1962; Zoll et al. 1956). All 
this laid the foundations for what would be modern "cardiopulmonary resuscitation". Also, during the 60s, emergency services grew considerably, beginning their development, incorporating new technologies, facilitating their access to vehicles that transported patients and, above all, with the popular realization of the importance of tending to cases of vital urgency, or emergency, with maximum efficacy (Lloret and Aregall). It was in this context that the emergency service of the Hospital de la Santa Seu i Sant Pau was developed and created, including four ambulances for the transfer of patients to the facility.

In general, the Spanish state raised to the challenge, and with few geographic and demographic disparities, began building health centres to cover these new forms of harm; until that moment, the public health system had depended economically and legislatively on municipalities, through the Health and Charity Boards (Lain 1973; Placer and Urkia 1993), and the health system promoted by the Franco dictatorship, with the establishment of the Seguro Obligatorio de Enfermedad (1942), and its construction of care facilities known as residencias, which were mainly surgical hospitals and did not contemplate urgent care.

In a study on the hospitals of Madrid published in 1961, and commissioned by the Dirección General de Sanidad, it became clear that hospital reform was essential for the subsequent evolution of Spanish healthcare, and to achieve the humanization of care. Most of the problems encountered in the capital also applied to the rest of the Spanish hospital network (García González 2011). The same report also discussed the advisability of having full-time doctors. ${ }^{2}$ It did not consider to emergency services, although it later states: "home care of patients from

\footnotetext{
${ }^{2}$ At the time, doctors generally weren't hired by hospitals. They visited patients in the morning and sometimes in the afternoon, but were mostly private practitioners. It was commonly said that they only visited the hospitals to learn from the various illnesses of people there, who were mostly poor and disenfranchised.
} 
public hospitals is totally non-existent, so it is recommended that a home care programme be developed and implemented, along with emergency facilities” (Martínez González 1962). Therefore, we can assume that, as in Catalonia, the existence of emergency services was very scarce or reduced.

In Barcelona it was a little different, because since the end of the 19th century there had been a permanent medical-sanitary system under the control of the city council, which was obliged to tend to the population in the event of medical emergencies, injuries or accidents. There was a casa consistorial, or casa de socors (relief house), in each district of the municipality, with a total of ten. The staff working there, doctors and practitioners, had to take special measures in the care of patients suffering from infectious diseases, which had to be compulsorily declared with the corresponding notification to the municipality. They were responsible for vaccinations and revaccinations free of charge, of all disenfranchised individuals, and were required to assist and care for the injured at any time of the day or night (Ajuntament de Barcelona 1885).

The kind of healthcare provided at the cases de socors came to cover needs that would otherwise go untreated for those who had no health insurance. In some Spanish capitals, these relief houses were necessary due to the lack of hospitals, and included milk banks for infant children (Gotas de leche); in others, the hospitals were not prepared to deal with these problems in an optimal way (Placer and Urkia 1993). This was the case of the Hospital de la Santa Creu i Sant Pau (HSCSP) de Barcelona, which, since beginning operations in the new location of the Guinardó district - from June 30th, 1916 until July 15th, 1927 - did not provide any service with these characteristics. 
This work is mainly based on the results of the research carried out for the preparation and defence of a Doctoral Thesis by the author of this article, entitled: "El Servei d'Urgències de l'Hospital de la Santa Creu i Sant Pau de Barcelona (1967-1986)", defended in January 2014 at the Universitat Autònoma de Barcelona.

Before starting this research, we wondered about the origins of hospital emergency services, and thus several questions arose: What were the origins of hospital emergency services? What phenomena led to the appearance of these services? What was previously in place at the Hospital de Sant Pau to provide emergency care? This is how the main objective of the study came about: To carry out an investigation on the origin, evolution and development of the Emergency Service in the "modern" era at the Hospital de la Santa Creu i Sant Pau de Barcelona, and its development over time, with special emphasis on the political, social, economic and/or demographic changes that occurred in the period studied.

\section{Methodology and documentary sources}

The methodology used in this work is Heidegger's (1889-1976) hermeneutic phenomenology. This method seeks the comprehension of reality with the objective of increased awareness. It is a method of historicist and dynamic conception, which takes into account human beings in their biological, psychological and social context (Cònsola 2008). Hermeneutic phenomenology considers what people say, their words, and the meaning they have, as an invaluable resource (Gálvez 2007).

In historical studies, the use of the scientific method must be aimed at answering questions, testing hypotheses through the evaluation and interpretation of the phenomena studied, through historical evidence, dealing with the past. The collection of data must be systematic and its 
interpretation must be rigorous, so as to facilitate the correct reconstruction of the facts. The researcher must verify the authenticity of the sources and clarify the meaning of the text following the hermeneutic methodology (Arratia 2005).

The unit of analysis of the study is the Emergency Service of the Hospital de la Santa Creu $i$ Sant Pau de Barcelona (Catalán 2012).

The participants are people who collaborated in this study with their testimonials. They were selected using non-probabilistic criteria of an intentional nature, following the snowball method as well as according to convenience (Gerrish and Lacey2008; Salamanca and Martín-Crespo 2007; Vasilachis de Gialdino et al. 2006). Therefore, the sampling was partly intentional; participants were chosen on the basis of their relevance to the investigation, so as to compare their statements with the documentation consulted and conforming to the researcher's accessibility (Gerrish and Lacey 2008).

The criteria for the inclusion of the participants was that they be involved with the Emergency Service of HSCSP in Barcelona at the time of its inauguration, so as to have direct and reliable information about the evolution in the functioning of the Emergency Service from its conception.

Different techniques were used for data collection; open-ended interviews were performed when the subject of study couldn't be observed, as they are often used in historical studies (Hernández, Fernández and Baptista 2010).

While to get documentary sources he went to: Josep Laporte Library of Barcelona, Historical Archive of the City of Barcelona, Historical Archive of the Hospital de la Santa Creu and Sant Pau, and Contemporary Municipal Archive of Barcelona. 
A second documentary source was books; the sample of the books read was chosen for their generalist as well as specific content on the history of HSCSP. Books were also read that contained relevant information about the social customs of our country, as well as the demographic changes that accompanied the great political changes that occurred in the period studied; the dictatorship, the transition period, and the arrival of democracy.

Thirdly, press articles were consulted and read as documentary sources: A sample of press from different ideologies and political tendencies was taken, even though during the dictatorship, published news underwent a censorship process, especially on issues related to politics. The criteria for the inclusion of press articles was that they either ratified or corroborated the information obtained in relation to the HSCSP and that their content referred to issues or conflicts dealt with in our study. Also considered were articles that provided information about local social movements which took place during the time period studied. All in all, we reviewed articles from the following outlets: Diario de Barcelona, La Hoja del Lunes, Solidaridad Nacional, TeleleXpres, La Vanguardia, El Observador, El Noticiero Universal, El Correo Catalán, Mundo Diario, La Prensa, ABC, El País, El Periódico and Avui.

The fourth source of documentation was the private documents provided by one of the sons of the first Director of the Emergency Service, Dr. Vicenç Artigas i Raventós, and the first Governing Board of the hospital. The minutes books of the MIA (Molt Il·lustre Administració, Very Illustrious Administration, in english), the Instrucciones permanentes del servicio de urgencias (868 articles), the internal publications of the hospital itself - Annals de Sant Pau (1919-1936), Annals de Sant Pau (1951-1977), Butlletins interns de l'Hospital de Sant Pau (1971-1996), Sant Pau (1980-1990), Fulls Informatius (1999-2000) - as well as the private 
archives of the Neighbourhood Associations of the Clot-Camp del Arpa, Sagrada Familia, and Guinardó areas.

The fifth source came from journals specialised in the sector such as Medicina Clínica (19671968), Estudios sobre hospitales y beneficencia (1961-1967), its complete collection, as well as Estudios sobre hospitales (1968-1980), ${ }^{3}$ Noticias Médicas (1969-1970), articles from different medical and nursing journals (Alonso et al. 2003; Aranaz et al. 2006; Berlango et al. 2000; Bueno and Sánchez 2005; Cabrer 1991; Castells 2006; Corbella et al. 2001; Duaso and López-Soto 2009; Hoyle 1995; Lucas et al. 2011; McKenzie 1991; Moreno 2004 and 2008; Nellessen 2009; Ortiz 2010; Oterino et al. 1999; Pasarín et al. 2006; Pearn 1998; Peña and Snyder 1995; Roig and Baró 2006; Safar 2001;Sánchez, Salgado and Miró 2008; Trabacchi 1997; Varon and Sternbach 1991 [these works are a sample]), as well as Annals de Medicina by the Academia de Ciencias Médicas (monographic) on the Emergency Service (2002).

Finally, some web pages were consulted: PubMed; ISOC; ISIS; Dialnet; EUREKA; and TDX. All of them provided some valuable information.

\section{The Emergency Service of the Hospital de la Santa Creu i Sant Pau}

The Origins

On the 30th of June 1916 began the transfer of patients from the old Hospital de la Santa Creu de Barcelona to the new location in the district of Guinardó. This process of transferring patients and services would take about 12 years. It wasn't until July $15^{\text {th }}, 1927$, a couple of years before the full transfer was completed, that an emergency care service was created, when

\footnotetext{
${ }^{3}$ Both were found in the Archives of the Hospital del Sagrat Cor in Barcelona.
} 
the Molt Il-lustre Administració (MIA) ${ }^{4}$ assigned an in-house team (named cos de guàrdia), staffing it with four doctors 5 .

The doctors on duty were there to provide emergency care to the hospital's patients as well as those who came through the entrance stations. ${ }^{6}$ At first, they were located on the right wing of the Administration building, ${ }^{7}$ but they later relocated to the basement floor of the central operating pavilion, near the delivery room. Towards the end of 1949, however, at the request of the Mare General, it was decided that, to aid the proper functioning of the service, it should be moved from the basement to the second floor of the same operating pavilion. It was set up as the "Emergency Room" of the other existing hospitals, - at that time, the Hospital de los Infecciosos and the Hospital Clínic -. So even though there was a minimal emergency service, it was not nearly enough to fulfil the needs of the city (López i Gibert 1977). This new medical service, the cos de guàrdia, operated as a de-facto emergency service, but it was not until the end of 1950 that we can find a document in which the Emergency Service is first called by this name (Cornudella 1971). ${ }^{8}$

On October 6th, 1950, the Administration of the HSCSP, in acknowledgement of his merits, granted Dr. Enric Ribas Isern (1897-1975) ${ }^{9}$ the direction of the Servei de Guardia, at that time

\footnotetext{
${ }^{4}$ The Molt Il-lustre Administració (MIA) was an administrative organization in charge of the Hospital de la Santa $\mathrm{Creu}$ since its creation in 1401. It was formed by two canons and two city councillors, an inheritance of the old Consell de Cent. The real power, however, was wielded mostly by the canons until well into the 1960s, as the councillors didn't concern themselves with the daily workings of the hospital. This gave the canons more weight in the decision-making processes, where the nuns and the priest had great influence.

${ }^{5}$ The doctors working at the cos de guàrdia were: Enric Lience, Vicenç Arnaldich Serradó, Manuel Negre Balet and Vicenç Jordán Navarro.

${ }^{6}$ The entrance police station was part of the existing hospital admission system at the Hospital.

${ }^{7}$ Annals de l'Hospital de la Santa Creu i Sant Pau (13),1-13, May 1927; Hospital de la santa Cruz y San Pablo Barcelona: 1930.

${ }^{8}$ See also "Nombramiento de médicos auxiliares. (1927)", Anales del Hospital de la Santa Cruz y San Pablo IV: 231.

${ }^{9}$ Enric Ribas Isern was an abdominal surgeon.
} 
still located in the basement of the central operating pavilion. However, three years later he would resign from the post due to what he claimed was a lack of support from the MIA.

While the HSCSP was deteriorating due to a clear lack of medical involvement and the cos de guàrdia was still without a head of service, startling news arrived in the form of an article published in the Annals de l'Hospital in 1964, which spoke of an Anglo-Saxon and Nordic contribution that had been gaining ground throughout Europe and the world, about the degree of medical involvement and dedication in hospitals. There was talk of full-time medical care within the hospital, that is, exclusive or full-time care within the same facility, something unthinkable until then.

This fact reaffirmed that hospital management had to change, and the HSCSP had already begun to do so with the arrival at MIA of Canonge Lluís de Despujol Ricart (1895-1981) in 1958. Canonge Despujol wanted to change the management of the hospital, introducing great shifts in the functioning of the institution and in the remuneration of the staff. He proposed doctors should receive proper remuneration for the first time, - it had been very small before, as after distributing the profits between the administration and the subordinate staff and other services, there was only a small part left for the head of each service to distribute with the collaborating doctors - This was not enough, and he would quickly understand that he alone could not make the changes that were necessary, so he got in touch with Carlos Soler Durall, manager of the General Hospital of Asturias.Carles Soler Durall was the son of a bacteriologist from the Hospital de los Infecciosos (now Hospital del Mar) who had gone into exile, to the United States. He had wanted to specialize in microbiology at Yale, but the untimely death of his father made him switch focus, onto hospital planning and management techniques. Once he returned to Spain, the President of the Provincial Council of Asturias, José Lopez Muñiz (1916-2005), 
took him on as manager at the General Hospital of Asturias where he carried out the duties of both manager and medical director. There, he would start applying certain techniques of hospital management still unknown in our country; this would make the local doctors reject him outright.

Carlos Soler, according to Reventós, "was surely for a time the most important man, not only in the Catalan health system, but also in the Spanish health system. Both in Oviedo and at Sant Pau, he led hospitals down paths previously unknown in our country." Hospital management (Alvarez 2009), then, was a relatively new concept in the health institutions of the time; the lack of any hospital policy under the Franco dictatorship forced hospitals throughout the country, and especially in Catalonia, to remain under the model of the domestic hospital, ${ }^{10}$ pretty much until the transition to democracy. This was why the first hierarchisation of a large hospital in Catalonia was that of the HSCSP. Dr. Soler justified it by stating that the 20th century would be the century of hospitals, that the evolution towards the modern concept of hospitals would soon take place. In fact, he based his argument on the Flexner Report (1910), which had proposed a new way of understanding the economy, administration and organisation of American hospitals (Barceló and Comelles 2020).

This management led to a great revolution at the national level, as different hospitals in the country, including the Hospital Clínico in Madrid, followed its guidelines during the reform of Spanish hospitals in the 1960s (Morán 2011). Dr. Soler incorporated the economy into the hospitals, he promoted monolithic hospitals and the centralisation of general services as a measure to save on hospital costs, as this meant savings in consumables, personnel and

\footnotetext{
${ }^{10}$ This is the name that was given to hospital facilities when, at the beginning of the $20^{\text {th }}$ Century, they began incorporating treatments that had previously been done at home.
} 
equipment. He also took part in the commission that would draw up the training programme for medical interns and residents to facilitate their medical specialization and professional development within the country.

He was appointed as General Director of HSCSP and in November of 1969, discussions began on the draft of new regulations for the HSCSP's facultative body, which would, among other things, discuss salary issues, bringing to light once again the disastrous existing criteria behind HSCSP's funding (Pedret 1969). Carlos Soler was entrusted with the construction of a new Emergency Service. The great responsibility involved in providing this type of care and its social repercussions meant that the appropriate provisions had to be made to guarantee the maximum level of care at all times. The director general himself proposed the appointment of the oldest deputy director of general surgery, Dr. Vicenç Artigas Riera (1908-1975), as director of the new service. He would devote six hours a day to supervising and coordinating the service, making it compatible with his other duties. He would be the one to organise the setting up of the new Emergency Service (MIA 1966).

In the regulations of the new service, the main objective was the assistance of patients who, susceptible to an alteration of their health, needed immediate assistance, whatever the nature of their illness. To this end, it was equipped with the adequate personnel and material means as well as a functional structure that would allow it to deal with those situations with maximum efficiency.

Additionally, this service was aimed at any person affected by a condition that would be worsened if they did not receive immediate assistance, as well as those people who needed assistance because they could not find it elsewhere. People could come in, safe in the knowledge 
that they wouldn't be discharged until the doctors had made sure there was no health risk in them doing so. As for hospitalised patients who had an emergency and who, due to the structure of their ward, could not be tended to, they would be transferred to the Emergency Service of the same hospital. Its inauguration took place on October 5th, $1967 .^{11}$

\section{Human Resources}

The Emergency Service would be an example of functional integration of all hospital services, since in addition to the specific structures of the Emergency Service, other specialised services and departments, doctors, medical-administrative and administrative staff would also work together in cooperation with the Emergency Service. It also had the permanent support of the Biochemistry and Haematology Laboratory, Blood Bank and Radiodiagnosis facilities. The general services of the hospital directly involved would be the departments of Nursing and Ambulance Service, Social Assistance, Admissions, Billing, and finally the conservation department and the hospital workshops.

In its organisation chart, the Emergency Service was made up of a unitary management and according to its director Vicente Artigas

"... with four doctors in charge of General Surgery, Traumatology, General Medicine and Anaesthesia, with a total of sixteen doctors assisted by a similar number of resident doctors. In addition, the Emergency Service has a medical team of more than fifty specialist consultants who are available to consult or operate, as the case may be, within less than an hour." (Llull 1968)

In this way, all the specializations of the hospital were involved in the new project.

\footnotetext{
${ }^{11}$ As noted in "Inauguración del servicio de urgencias del Hospital de San Pablo." La Vanguardia, January 23, 1968; "La urgencia de las urgencias." La Vanguardia, October 10, 1967, and in "Nuevo servicio de urgencias en el Hospital de la Santa Cruz y San Pablo." La Vanguardia, October 5, 1967. See also Puig 1977; and Servicio de urgencias 1967 Hospital de la Santa Cruz y San Pablo.
} 
The Executive Committee of the Emergency Service was presided over by an administrator assigned by the MIA, and was made up of the general director, the director of the Emergency Service, the head of the hospital's administrative division and the head of the medicaladministrative division. The objective of this commission was to periodically review and monitor the evolution of the Emergency Service, so there was awareness at the highest level of management of the realities of the department. At the same time, this first-hand knowledge of their needs as they arose allowed for the adaptation of their policy according to their situation and guaranteed that any problems within the service were known within the MIA (Soler 1967).

The staff that made up the crew of the new service at the time of its inauguration was composed of its director, Vicente Artigas Riera, and together with him, four Internal Medicine doctors, four Traumatology doctors, four General Surgery doctors and four Anaesthesia doctors; the same number of resident doctors for each speciality, plus three radiology doctors. As for the nursing staff, which depended on the nursing department, there was a General Supervisor, thirty nurses, eighteen assistants, four radiology technicians, six radiology assistants, four receptionists, one secretary, ten sanitary personnel and seven cleaners. In total, it was a team of 121 people, who were at the service of the citizens of Barcelona and the rest of Catalonia (Vila 2014).

Dynamics of the Emergency Service

For the proper functioning of the service, the functions of each professional category that was part of the team had to be properly delineated and described. To this end, the Instrucciones permanentes del servicio de urgencias were drawn up and presented by Carles Soler Durall to the MIA. This way, Carles Soler repeated what he had already done at the General Hospital of 
Asturias (García González 2011), where he had had the permanent instructions of the services and departments of the centre drawn up.

The first thing a person found upon arriving at the Emergency Service was the admissions area; an entrance door for ambulances and cars that ended up in a corridor where, on the right side, were the authorities and press department and different waiting rooms for patients and families, while on the left side, was the reception and social worker. In the event of detecting any social problems, the latter tried to find solutions while the patient was being visited by the emergency team. On the same side, on the left, were the doors of four first aid cubicles, where the patients entered directly from the vehicle into the cubicle, the purpose being that medical assistance could begin without delay. These cubicles were equipped with all the necessary tools for assistance of any kind. ${ }^{12}$ The operating theatre area consisted of an operating theatre anteroom, two operating theatres, an anaesthetic induction room and an air-conditioning and machine room.

In the clinical area was the intensive care unit, where seriously ill patients were placed. It had a semi-circular shape with a total of six individual sections arranged around a central control point from where both the medical and nursing staff had a direct view of all of them. In this way, variations in their physiological state were easily monitored and detected, since the pulse, breathing, blood pressure, temperature and electrocardiogram were electronically controlled with continuous graphic records for each of the patients, with pre-established alarms on an individual basis (Vila 2014).

\footnotetext{
${ }^{12}$ According the interview to M.T. Forner, December 3, 2007. See also Soler (1967).
} 
The main entrance to the hospital gave way on the right-hand side for the entrance to the service, an exclusive entrance for the new Emergency Service, located in a preferential area of the hospital, easily accessible from Avenida Gaudí itself, which guaranteed the fluidity of vehicle traffic, with an entrance permanently open to the interior of the service with a perfect connection with the rest of the hospital.

This was an advanced service in the technology of its time, with an intensive care unit shared with the rest of the hospital. Thanks to the good press it generated, for a few years it was one of the most crowded emergency services in the city of Barcelona. ${ }^{13}$

In spite of being a leading service, there was a grave mistake in its design: It didn't take into account the patients who arrived on foot to the Emergency Service. They did not have a parallel entrance circuit but had to access through the same door as the motor vehicles. Only once they got inside could they find the reception counter, where the desk clerk and the social worker were located. This led to criticism from other centres which had a minimal emergency structure and saw in the new service at Sant Pau an important rival; one that with its technology, was changing public perception and would force them to provide new approaches in terms of care and operation. However, various media sources from the era considered it one of the best emergency services at the time. ${ }^{14}$

\footnotetext{
${ }^{13}$ As noted in "Barcelona celebró el XXIX aniversario de su liberación con importantes inauguraciones y entregas de medallas y premios de la ciudad.” ABC, January 27, 1968. See also Reventós 2003; Soler 1967.

${ }^{14}$ Pointed in "El nuevo servicio de urgencias." La Vanguardia, January 26, 1968; "Barcelona celebró el XXIX aniversario de su liberación con importantes inauguraciones y entregas de medallas y premios de la ciudad." $A B C$, January 27, 1968; Also Soler 1967.
} 


\section{Economic Resources}

The economic costs and income of the service would be the object of specific departmental accounts, maintained by the economic department of the hospital, in which everything that had occurred on each date would be recorded, classified by general budgetary concepts, and a monthly summary would be established. They would also include an unrelated part of the hospital's general expenditure, which would be established in a fixed amount for an entire financial year, at the beginning of the year. Depreciation costs would also appear as expenses, calculated by dividing the price of each depreciable asset by the expected duration of each material element. All receipt or collection of money from patients treated in the Emergency Service was exclusively made by the sub-cashier that existed next to the hospital's billing section on the same floor as the Emergency Service, controlled by personnel specifically authorised by the billing section itself, at times when the cashier desk was closed (Vila 2014).

Cases of total or partial charity, agreements or third party liabilities were managed by the appropriate charity or agreement sections, following normal procedure. For this purpose, the invoicing section connected the interested parties with other sections. Users were charged for the services in accordance with previously established tariffs. In the light of practical experience and accounting data, the tariffs were revised, incorporating any possible modifications, duly signed by the general manager. The express ideal to strive for was that the tariffs per unit of service should coincide exactly with the real cost, regardless of the economic qualification of the patient.

From the day of its inauguration, the service was adapted according to the needs of the demand that existed, but it was not until 1980, with the inauguration of the paediatric and the 
gynaecologic branches of the Emergency Service, that the Hospital achieved its goal of providing all kinds of specialized emergency care.

Continued training, the basis for good care

Dr. Artigas was a highly regarded teacher by his students, both the students of the HSCSP School of Medicine and the students of the HSCSP School of Nursing. His passion for teaching and learning made him a traveller who went looking for what he could learn where he could be taught. This meant that throughout his life he developed research studies with his surgical teams and invited them to make them public in different events around the world, and in this way he got a whole team - and at the same time a whole Emergency Service - to understand the need for good continuous training; necessary at the beginning, with the opening of the service, and necessary over time, to ensure all its professionals were at the highest level, as the times demanded (Benito 1977; Puig 1977).

Appearance of Emergency Service collapses

On January 28th, 1975, due to a flu epidemic, the hospital was saturated and once the Provincial Health Department had been notified, it closed its doors for a few hours. This fact was considered unfathomable by Barcelona society, as an Emergency Service was supposed to be kept open 24 hours a day. But the lack of beds in the Catalan capital meant that permanent care became a difficult objective to achieve. This serious situation was publicised on a national level, ${ }^{15}$ since it was the first time that an Emergency Service in Barcelona had collapsed in such a visible way.

\footnotetext{
${ }^{15}$ As noted in "El Hospital de la Santa Cruz, saturado." $A B C$, January 31, 1975; "El Hospital de San Pablo, saturado." Diario de Barcelona, January 30, 1975; and Pedret 1975.
} 
This highlighted the lack of hospitalisation beds in the city of Barcelona and the lack of emergency services. This lack of healthcare resources in the city produced great concern among the population and in the hospitals which were overloaded with work and without sufficient resources. This was clearly a problem for the community, which, through the media, called for an increase in the amount of both public and private hospitals and therefore an increase in the number of beds in the city. ${ }^{16}$ This press release was drawn up by Josep Jover, Director of the HSCSP Emergency Service, a position he held until 1990. ${ }^{17}$

He had been one of the founding members of the Emergency Service and therefore marked and guaranteed the continuity of the task carried out by Dr. Vicenç Artigas, who was transferred a few days after the first collapse. The new director's leadership developed at a time of great political, social and economic change. In February 1975, an article was published in the press announcing that the hospital was once again experiencing financial problems. In spite of everything, the Sant Pau hospital had made a great effort to update all its services and found that when it came to asking for help from the Instituto Nacional de Prevision (INP), the latter did not take responsibility, because it gave priority to the two other facilities it had built in the region, which it considered a benchmark on an international scale. ${ }^{18}$

In June of the same year, 1975, a strike by hospital workers once again put the capacity of the Emergency Service to the test. This was the only service that maintained its normal activity, despite the labour conflict, without presenting any additional problems (Capdevila. 1975). ${ }^{19}$

\footnotetext{
16 See "Déficit alarmante." La Vanguardia, January 31, 1975. "El Hospital de la Santa Cruz, saturado." $A B C$, January 31, 1975; "Hospitales: toque de alerta.” La Vanguardia, November 1, 1975; and Pedret 1975.

${ }^{17}$ See "Sensible pérdida." Boletín del Hospital de la Santa Cruz y San Pablo, 1975).

${ }^{18}$ Pointed in "El Hospital de San Pablo, saturado." Diario de Barcelona, January 30, 1975.

${ }^{19}$ See also the article "Paro en el Hospital de San Pablo." La Vanguardia, June 3, 1975.
} 
During the months of March and April 1976, two more closures of the HSCSP Emergency Service due to collapse occurred. Specifically, on March 23rd, due to overcrowding, those with minor injuries were asked to go to other health centres in the city, while the press continued its denunciation of Barcelona's hospital deficit.$^{20}$ The same thing happened again on the April 3rd of the same year, with its corresponding denunciation in a press release. ${ }^{21}$

As a result of these repeated incidents, a social movement began to spread to all the neighbourhoods of the Catalan capital. A committee was formed by the neighbourhood associations (AAVV) of the areas around the hospital, along with Josep Jover, head of the HSCSP Emergency Service, and Dídac Amat, head of Public Relations at the same centre, working as secretary of the committee (Servicio de Relaciones Públicas 1976).

This committee drafted a document that was sent to the director of the Provincial Delegation of Barcelona of the Instituto Nacional de Previsión (INP), Joaquín Busquets Ducet (1916-1998), at its headquarters in Barcelona, with a copy sent to the civil governor, Rodolfo Martín Villa, and to the mayor of the city, Joaquín Viola Sauret (1913-1978), inviting the INP to carry out a plan for the viability and improvement of emergency medical care in the city. ${ }^{22}$ The document mentioned the serious lack of hospital centres in the city of Barcelona to care for emergencies, which caused the collapse of the few existing ones, and that this problem could not be solved as long as it continued to lack 20.000 beds (Servicio de Relaciones Públicas 1976). The commission therefore proposed that, as urgently as possible, public assistance in the city should

\footnotetext{
${ }^{20}$ As pointed in "No ha habido aumento significativo de la gripe este año." La Vanguardia, March 25, 1976; "Notable déficit Hospitalario en Barcelona. Cierre provisional del servicio de urgencias del Hospital de San Pablo." La Vanguardia, March 24, 1976.

${ }^{21}$ Noted in "Barcelona: Nuevo cierre provisional del servicio de urgencias del Hospital de San Pablo." La Vanguardia, April 4, 1976.

${ }^{22}$ See "Interesante programa de colaboración entre asociaciones de vecinos y el Hospital de San Pablo." La Vanguardia, April 4, 1976; and "Preocupación por la situación sanitaria de Barcelona." ABC, May 26, 1976.
} 
be zoned and that this zoning should be public, making this information available to all citizens, so that each person could know which centre to go to when they required urgent attention.

During the following months, until July 1976, other citizens with important positions in civil society joined the project for the improvement and coordination of the city's hospitals, with the express objective of preventing another the collapse of the emergency services ${ }^{23}$

In October 1976 the AAVV, together with representatives of the Hospital Clinic and the HSCSP, sent a letter similar to the previous one. This new letter, however, was to be sent to the Management of the INP, in Madrid. Nine months before, the letter had been sent to the Barcelona delegation, which responded that the matter raised was beyond their competence and had to be sent to the central services. So, for a second time, this time at the onset of winter, with the addition of the Hospital Clínic and twenty-two other associations, it was delivered again (Servicio de Relaciones Públicas 1976).

Barcelona did not stand still, until finally, on June 3rd, 1977, most likely as a result of the awareness campaign carried out through the neighbourhood associations, a response was received from the central services of the INP. ${ }^{24}$ It stated that they had instructed the provincial delegation of Barcelona, as well as the rest of Spain, to take the necessary measures to structure the coordination and sectorisation of the emergency services of the health institutions belonging to the Social Security and in the semi-private hospitals with increased functionality. ${ }^{25}$

\footnotetext{
${ }^{23}$ Noted in "Más adhesiones ciudadanas al proyecto de urgencias." Boletin del Hospital de la Santa Cruz y San Pablo, 1976, 14.

${ }^{24}$ As pointed in "Respuesta favorable del INP a la propuesta de mejora y coordinación de las urgencias." Butlletí de l'Hospital de la Santa Creu i Sant Pau., 1977, 3.

25 See "Al habla con gerència." Boletin del Hospital de la Santa Cruz y San Pablo, September 1, 1977; “Coordinació de les urgències." Butlletí de l'Hospital de la Santa Creu i Sant Pau. 1977, 23.
} 
At the beginning of March 1979, the first steps were taken in the project of the sectorisation of Barcelona, assigning each emergency centre a specifically delineated area to provide care for. Excluded from the sectorisation were vital emergencies, which would be tended to in the nearest centre possible. To establish each area, the natural setting, road traffic and access to the facilities, the capacity of the hospitals and the number of emergencies generated by each area per thousand inhabitants were taken into account (Servicio de Relaciones Públicas. 1979). ${ }^{26}$

At the same time as the above events, Soler Durall left in 1970 and Mrs. Elvira Guilera Soler joined as manager. Despite being a continuator of the task set out by her predecessor, she opened the concert with the Social Security in order to survive and deal with the payroll of the new staff and doctors who, being of a different generation, demanded to have a payroll at the end of the month. As a result of all this, a serious conflict arose with the INP, which even endangered the continuity of the hospital itself. During this crisis, the management of the hospital was changed and a Governing Board was formed to take charge of the hospital's management, leaving only the management of assets in the hands of MIA.

The Governing Board was to start work immediately, with the aim of transforming the hospital into a public service entity (“Junta de Govern de l'HSCSP. Butlleti de l'Hospital de la Santa Creu i Sant Pau, 1978: 1 ater, the Consell d'Usuaris (People's Council) would be created, and immediately get to work. The first thing it did was to set itself some objectives that would represent its values, its reason for being, its seriousness and above all the need to be an entity that was representative of a population that was starting to be the protagonist of an important change in the whole country.

\footnotetext{
${ }^{26}$ See also "Por teléfono podrá consultarse cualquier tema médico-sanitario.” La Vanguardia, October 28, 1979.
} 
The HSCSP's Consell d'Usuaris was based on the principles of the inalienable defence of the patients' rights, support for the transformation of the hospital into a public service with an internal democratic, participatory structure and with total transparency in management. Without doubt, the two most important actions carried out by the Council in its first period were the drafting of the "Declaration of Patients' Rights" and the creation of the Suggestions and Complaints Service.

In the same year, 1978, the Ministry of Health created the National Institute of Health (INSALUD), a body that would replace the INP. Its main purpose was healthcare management. This body's purpose was to modernise the country's health system, decentralising health services to the Autonomous Communities, as soon as the General Health Law was passed in 1986, but this transfer was extended until 2001, when the body disappeared for good (Catalán 2012).

\section{Conclusions}

The new epidemiological paradigm of medical-surgical emergencies that appeared as a consequence of the industrial revolution, most developed in our country in the mid-20th century, arose before the health system was prepared to assume these new challenges, and it was, at first, the cases de socors that were forced to take on that responsibility, entrusted to alleviate the existing deficiencies in Spanish society at the time. This new epidemiological paradigm would be the main phenomenon which would lead to the appearance of the emergency services in the new era which was beginning.

The saturation and temporary closure, in 1975, of the city's new Emergency Service was the first warning sign about the shortage of hospital beds in the Catalan capital. This social 
emergency was denounced by the media and supported by the press release signed by the director of the HSCSP Emergency Service. When another collapse situation arose the following year, a social movement started which, in its inception, was formed by the neighbourhood associations of the areas around the hospital, as well as the head of the emergency service and the head of public relations of the same facility. This commission would prepare a document that would be sent to the director of the Barcelona Provincial Delegation of the National Institute of Forecasting (INP), at its Barcelona headquarters, with a copy to the civil governor, and to the mayor of the city, inviting the INP to carry out a plan for the viability and improvement of emergency medical care and the zoning of the city.

While waiting for the response, the citizens' mobilisations and the workers' labour protests to strengthen their healthcare demands were spread throughout the city, and after a few months of waiting for a response, a new document was drafted, this time to be sent to the INP's headquarters in Madrid, which was signed by the previous groups, as well as Hospital Clínic and twenty-two other associations. This movement spread to other cities in Spain, until the state's reply finally arrived, stating that they had sent instructions to the provincial delegation in Barcelona, as in the rest of Spain, to take the appropriate measures to be able to structure the coordination and sectorisation of the emergency services of the health institutions belonging to the Social Security and in the subsidised hospitals with added functionality.

The management promoted by Dr. Soler contributed to the change of paradigm of the hospitals, which went from being daytime reception centres to being considered a decisive health resource accessible 24 hours a day for the whole population, which turned current society into a hospitalcentric one. But his training in a completely private healthcare system, such as the one present in United States, where everything has a price, made him totally distrustful of the INP. This 
contributed to the economic problems of the hospital and the projects it presented to the MIA board. Simultaneously, the social movements were beginning to carry a lot of weight, which led to the departure of Dr. Soler, with Mrs. Elvira Guilera Soler as the new manager, who despite being a continuist, opened the concert with the Social Security to be able to survive and provide the much-needed payroll for the new staff and those doctors who demanded to have a payroll at the end of the month.

However, a series of serious conflicts began to appear, which led to changes in the management of the hospital, with a Governing Board being set up to take charge of hospital management, leaving only the handling of patrimonial assets in the hands of MIA. It was the first time that, at a state level, an organism created by the patients and users of a healthcare centre had come to have representation within a public organization, a change the effects of which would ripple out well into the future.

\section{Documentary Sources}

\section{Minute books}

MIA. 1966. Llibre d'actas de les sessions celebrades a l'Hospital de la Santa Creu i Sant Pau. Barcelona, October, 20

MIA. 1967. Llibre d'actas de les sessions celebrades a l'Hospital de la Santa Creu i Sant Pau. Barcelona, March 3.

\section{Interviews}

Vicenç Artigas i Raventós, Head of Service of the Hospital de la Santa Creu i Sant Pau (April 5th, 2009). Maria Teresa Forner, Hospital del Mar de Barcelona (December 12th 2007). 


\section{References}

Ajuntament de Barcelona. 1885. Servicio médico-sanitario permanente de la ciudad de Barcelona. Barcelona: Establecimiento tipográfico de los sucesores de N. Ramírez y Ca .

Alegre Marcet, C. 1962a. "Plan para el futuro de los Hospitales britanicos." Estudios sobre Hospitales y beneficència 12: 27-29.

Alegre Marcet, C. 1962b. "Supresión de las salas comunes en el Hospital. La experiencia del centro Hospitalario de Belfort." Estudios sobre Hospitales y beneficencia 9: 58-60.

Sánchez, Miquel, Òscar Miró, Blanca Coll-Vinent, Ernest Bragulat, Gerard Espinosa, Elisenda GómezAngelats, Sònia Jiménez, Carme Queralt, Josep Hernández-Rodríguez, Josep R Alonso, José Millá. 2003. "Saturación del Servicio de urgencias: factores asociados y cuantificación." Medicina Clínica.121(5): 161-172.

Aranaz Andrés, Jesús, Rafael Martínez Nogueras, María Teresa Gea Velàzquez de Castro, Vicenta Rodrigo Bartual, Pedro Antón García, Fernando Gómez Pajares. 2006. “¿Por qué los pacientes utilizan los servicios de urgencias hospitalarios por iniciativa pròpia?." Gaceta Sanitaria 20(4):

311-315. http://scielo.isciii.es/scielo.php?script=sci arttext\&pid=S0213-91112006000400010.

Arratia F., Alejandrina. 2005. "Investigación y documentación histórica en enfermería." Texto Contexto Enferm, Florianópolis 14(4): 567-574. doi: 10.1590/S0104-07072005000400014.

Artigas Candela, José. 1975. “La Ley de Hospitales Belga.” Estudios sobre Hospitales 69: 27-35.

Artigas Candela, José. 1976. “Organización de la sanidad en Finlandia.” Estudios sobre Hospitales. 76. Alguacil Gómez, Julio. 2002, “Asociaciones vecinales.” In Enciclopedia Madrid s. XX, edited by Carlos Sambricio, 29-31 Madrid: Ayuntamiento de Madrid.

Álvarez, Pablo. 2009. "Poner en marcha el Hospital General de Asturias fue la experiencia más gratificante de mi vida [interview with Carlos Soler Durall]." La Nueva España, February 22. https://www.Ine.es/sociedad/2009/02/22/poner-marcha-hospital-general-asturias21572033.html.

Aragó, Ignasi. 1967. Els Hospitals a Catalunya. Barcelona: Altés.

Aragó, Ignasi. 1968. "Ministerio de Saude e Assistencia (Portugal)." Estudios sobre Hospitales y beneficencia 29: 5-6.

Barceló Prats, Josep, and Josep M. Comelles. 2020 L'evolució del dispositiu hospitalari a Catalunya (1849-1980). Barcelona: Publicacions de l'arxiu històric de les ciències de la salut PAHCS.

Benito, Salvador. 1977. "El Doctor Artigas segons els seus alumnes.” Annals de Medicina 63(1): 70-71. http://webs.academia.cat/revistes_elect/view_document.php?tpd=2\&i=5738.

Beuran, M. I. Negoi, S. Pãun, A. Runcanu, and B. Gaspar. 2011. "Istoria îngrijirii pacientului traumatizat 
[History of trauma care]. Chirurgia (Bucur) 106(5): 573-580. https://www.revistachirurgia.ro/pdfs/2011-5-573.pdf.

Boyd, David R. 2010. "Trauma systems origins in the United States." Journal of Trauma Nursing 17(3): 126-134. doi: 10.1097/jtn.0b013e3181f5d382.

Bueno Cavanillas, Aurora, and J. Sánchez López. 2005. "Factores asociados al uso inadecuado de un servicio de urgencias Hospitalario." Emergencias 17(3): 138-144.

Cabrer, B. 1991. "Saturación de los Servicios de urgència Hospitalària." Medicina Integral, 18(3): 9192.

Capdevila, J. 1975. “Sant Pau: así funciona un Hospital en paro.” Diario de Barcelona.

Castells, Xavier. 2006. "Comentario, Utilización de los Servicios de urgències Hospitalarios. La importància de la perspectiva de los usuarios." Gaceta Sanitaria 20(2): 91-100.

Catalán Sesma, José María. 2012. 35 años de Sanidad democrática en un mundo cambiante. Madrid: Gramadosa SL.

Cònsola, Francesc. 2008. "Antropologia i recerca en els àmbits de les Ciències de la Salut.” Ars Brevis 14: 66-84. https://www.raco.cat/index.php/ArsBrevis/article/view/137022.

Cornudella, Josep. 1971. "El trasllat al nou Hospital de la Santa Creu i de Sant Pau." In L'Hospital de Santa Creu i de Sant Pau. L'Hospital de Barcelona, Various Authors, 145-155. Barcelona: Editorial Gustau Gili, SA.

Departament of Health Edinburgh. 1963. "Plan Hospitalario para Escocia." Estudios sobre Hospitales y beneficencia 15: 38-43.

Domingo i Clota, Miquel, and Maria Rosa Bonet i Casas. 1998. Barcelona i els moviments socials urbans. Barcelona: Editorial Mediterrània SL.

Duaso, Enric, and Alfons López-Soto. 2009. "Valoración del paciente frágil en urgencias." Emergencias 21(5): 326-369.

Dunand, J.P. 1974. "La Organización Hospitalaria en Francia.” Estudios sobre Hospitales. 68: 49-63.

Elam, James O., Elwyn S. Brown, and John D. Elder. 1954. "Artificial respiration by mouth-to-mouth method: a study of the respiratory gas exchange of paralyzed patients ventilated by operator's expired air. New England Journal of Medicine 250(18): 749-754. doi: 10.1056/nejm195405062501801.

Elam, James O. 1977. "Rediscovery of expired air methods for emergency ventilation." In Advances in Cardiopulmonary Resuscitation. Edited by Peter Safar and James O. Elam, 263-265. New York: Springer-Verlag.

Escarribill, J., X. Corbella, A. Salazar, J.L. Sánchez. 2001. "Los colapsos en los servicios de urgencias hospitalarios durante el invierno.” Atención Primaria 27(2): 137-140. https://www.elsevier.es/es- 
revista-atencion-primaria-27-pdf-S0212656701787872.

Evans, David C. 2007. "From trauma care to injury control: a people's history of the evolution of trauma systems in Canada." Canadian Journal of Surgery 50(5): 364-369.

Ferret, Antoni. 1992. Compendi d'història de Catalunya II. Franquisme i transició democràtica. Barcelona: Claret.

Fuenmayor i López, Dulce. 2001. Història de la Infermeria a l'Hospital de la Santa Creu i Sant Pau. Barcelona: Fundació Privada Hospital de la Santa Creu i Sant Pau.

Gálvez, Alberto. 2007. Evaluación de la calidad de los diseños de investigación (IV). Investigación cualitativa descriptiva e interpretativa. Granada: Fundación Índex.

García González, José. 2011. La implantación del Hospital moderno en España. El Hospital General de Asturias, una referencia imprescindible. Oviedo: Ediciones Nobel.

Gerrish, Kate, and Anne Lacey. 2008. Investigación en enfermería. Madrid: McGraw-Hill Interamericana de España.

Hernández Sampieri, Roberto, Carlos Fernández Collado, and María del Pilar Baptista Lucio. 2010. Metodología de la investigación. México. Mc Graw Hill.

Hori, Shingo. 2010. "Emergency medicine in Japan." Keio J Med. 59(4): 131-139. doi: $10.2302 / \mathrm{kjm} .59 .131$.

Hoyle, J R. 1995. "The development of immediate care services in the United Kingdom." The History of anaesthesia society proceedings 18: 30-33.

Jaén, J. 1964. "Organización sanitaria y Hospitalaria en Suiza." Estudios sobre Hospitales y beneficència 17: 50-64.

Kouwenhoven, William B., James R. Jude, and G. Guy Knickerbocker. 1960. "Closed-chest cardíac massage." Journal of the American Medical Association 173(10): 94-97. doi: 10.1001/jama.1960.03020280004002.

Laín Entralgo, Pedro. 1973. La Medicina actual. Madrid: Seminarios y Ediciones SA.

Lown Bernard, Raghavan Amarasingham, and José Neuman. 1962. "New method for terminating cardiac arrhythmias: use of synchronized capcitor discharge." Journal of Americant Medical Association 182: 548-555.

Lloret, Josep, and Salvador Aregall. 2002. "Reflexions sobre el passat, present i futur dels serveis Hospitalaris d'urgències." Annals de Medicina 85(3): 122-125. https://www.raco.cat/index.php/AnnalsMedicina/article/view/143499.

López i Gibert, J. 1977. "El Doctor V. Artigas i el Servei d'Urgències.” Annals de medicina. 63(1): 6365.

Lucas Imbernon, F.J., M.A. Galán Traba, and R, Roldán Ortega. 2011. "La actividad asistencial en el 
servicio de urgencias hospitalario genera conflictos éticos a sus profesionales." Emergencias 23(4): 283-292.

Llull, Albert. 1968a. "Un nuevo servicio medico de urgencia en Barcelona.” ABC, April 19.

Llull, Albert. 1968b. "A beneficio del Hospital de la Santa Cruz.” ABC, November 21.

Martínez González, M. 1962. "Informe general sobre Hospitales por la comisión de estudios de los Hospitales de Madrid.” Estudios sobre Hospitales y beneficencia. 9: 10-17.

McKenzie, A., and J. Hodgson. 1991. "The emergency medical services of Scotlandfrom 1939: a retrospect." Health Bulletin 49(6), 304-313.

Mehrotra, Abhishek, David P. Sklar, Vivek S. Tayal, Keith Kocher, Daniel A. Handel, and R. Myles Riner. 2010. "Important historical efforts at emergency department categorization in the United States and implications for regionalization." Academic Emergence Medicine 17(12): 154-160. doi: $\underline{10.1111 / \mathrm{j} .1553-2712.2010 .00931 . x}$.

Montero, F.J., J.M. Calderón de la Barca Gázquez, L. Jiménez Murillo, A. Berlango Jiménez, and L. Pérula de Torres. 2000. "Situación actual de los Servicios de Urgencias Hospitalarios en España. I: Descripción general y anàlisis de la estructura física y funcional.” Emergencias 12(4): 226-236.

Morán, J. 2011. "El Hospital general de Asturias era el mejor y nuestro modelo en el Clínico de Madrid. [interview with Paloma Castillo]." La Nueva España, May 2. https://www.lne.es/asturias/2011/05/02/hospital-general-asturias-mejor-modelo-21109254.html.

Moreno Millán, Emilio. 2004. "36 años de Medicina de Urgencias y Emergencias, y Medicina Intensiva en España." Puesta al Día en Urgencias, Emergencias y catàstrofes 5(4): 167-178.

Moreno Millán, Emilio. 2008. "Y si adaptáramos los servicios Hospitalarios de urgencias a la demanda social y no a las necesidades de salud?" Emergencias 20(4): 276-284.

Mullins, Richard J. 1999. "A historical perspective of trauma system development in the United States." Journal of Trauma: Injury, Infection, and Critical Care 47(3 Suppl.): 8-14. doi: 10.1097/00005373-199909001-00004.

Nellessen, Karl-Wilhelm. 2009. Krankentransport Rettungsdienst und im Kreis Aachen 1816-2006: Geschichte einer kommunalen Dienstleistung. Aachen: Verlag Mainz.

Ortiz, Francisco Javier. 2010. "Valoración funcional en los servicios de urgencias Hospitalarios." Revista Española de Geriatría y Gerontología 45(2): 59-60. doi: 10.1016/j.regg.2009.11.005.

Oterino, D., S. Peiró, R. Calvo, P.Sutil, O. Fernández, G. Pérez, P. Torre, M.A. López, and T. Sempere. 1999. "Utilización inadecuada de un servicio de urgencias Hospitalario. Una evaluación con criterios explícitos." Gaceta Sanitaria 13(5). 361-370. doi: 10.1016/S0213-9111(99)71387-7

Pasarín, M Isabel, M. José Fernández de Sanmamed, Joana Calafell, Carme Borrell, Dolors Rodríguez, Salvador Campasol, Elvira Torné, M. Glòria Torras, Alex Guarga, and Antoni Plasència. 2006. 
"Razones para acudir a los servicios de urgencias Hospitalarios. La población opina." Gaceta Sanitaria.20(02): 91-99.

Pearn, J. 1998. "A history of first aid in Australia: the evolution of preHospital care.” Medical Journal of Austràlia 168(1): 38-40.

Pedret Muntañola Juan. 1969. "Los problemas del Hospital de la Santa Cruz y Sant Pablo. ECONOMICO: Probable solución en tres meses." La Vanguardia, November 11.

Pedret Muntañola, Juan. 1975. "Un grave problema: la insuficiencia de camas Hospitalarias." La Vanguardia, January 31, 1975.

Pena, Margarita E., and Brenda L. Snyder. 1995. "Pediatric emergency medicine: the history of a growing." Emergency Medicine Clinics of North America 13(2): 235-253.

Phillips, Joseph B., Donald Barker, Julie Dunn, and Blaine Ebderson. 2005. "Tennessee trauma care system plan, Part 1." Tennesseee Medicine, 98(3): 135-137.

Picolo i Berné, Raquel. 2004. 50 anys, Escola Universitària d'Infermeria. Hospital de la Santa Creu i Sant Pau. Barcelona.

Placer Galán, Carlos, and José María Urkia. 1993. El cuarto de socorro de San Sebastián. Origen y desarrollo (1881-1936). San Sebastián: Instituto Dr. Camino. Obra social de la Caja Gipuzkoa San Sebastian.

Poirson-Sicre, Sandrine. 2000. La médicine d'urgence prehospitalière à travers l'historie. Paris: Editions Glyphe i Biotem,

Puig i la Calle, Jordi. 1977. "Recordant el doctor Artigas." Annals de Medicina 63(1): 66-69. http://webs.academia.cat/revistes elect/view document.php?tpd=2\&i=5737.

Ramis, Juan, and Santiago Torres Sanahuja. 1973. "Concepto de Hospital integrado en Rumania." Estudios sobre Hospitales 61: 39-47.

Reventós, Jacint, Anna Garcia, and Carme Piqué. 1990. Història de la medicina catalana sota el franquisme. Barcelona: Hacer Editorial.

Reventós i Conti, Jacint. 1996. Història dels hospitals de Catalunya. Vol. I: Els Hospitals i la societat catalana. Barcelona: Hacer Editorial.

Reventós i Conti, Jacint. 2003. Història dels hospitals de Catalunya. Vol VIII: Els Hospitals de Barcelona i el Barcelonès. Barcelona: Viena edicions.

Rey Carrera, Juan. 1963. Moral profesional del Ayudante Técnico Sanitario. Santander: Sal Terrae.

Rockwood, Charles A., Colleen M. Mann, J.D. Farrington,, Oscar P. Hampton, Robert E. Motley. 1976.

"History of emergency 260enefic services in the United States." Journal of Trauma: Injury, Infection, and Critical Care. 16(4): 299-308. Doi: 10.1097/00005373-197604000-00008.

Roig, Josep, Purificació Merino, and Joan Baró. 2006. De la residència a Hospital d'alt nivell. 50 anys 
de l'Hospital Dr. Josep Trueta de Girona (1956-2006). Girona: Deparatment de Salut, Generalitat de Catalunya. http://www.icsgirona.cat/adjunts/files/llibre.pdf.

Safar, Peter, Lourdes A. Escarraga, and James O. Elam. 1958. "A comparison of the mouth-to-mouth and mouth-to-airway methods of artificial respiration with the chest-pressure arm-lift methods." New England Journal of Medicine 258: 671-677. Doi: 10.1056/NEJM195804032581401.

Safar, Peter J. 2001. "On the history of emergency 261enefic services." Bulletin of Anesthesia History 19(3): 4-8. Doi: 10.1016/S1522-8649(01)50031-1.

Salamanca, Ana Belén, and Cristina Martín-Crespo Blanco. 2007. "El muestreo en la investigación cualitativa." Nure Investigación https://www.nureinvestigacion.es/OJS/index.php/nure/article/view/340/330.

Salarich, J. 1973. "Manual de urgencias médicas y quirúrgicas." Review of the Manual de urgencias médicas, directed by Vicente Artigas. Anales de Medicina y Cirugía 54(236): 211-212.

Sánchez, Miquel, Emilio Salgado, and Òscar Miró. 2008. "Mecanismos organizativos de adpatación y 261eneficència261 de los 261eneficèn de 261eneficè." Emergencias 20(1): 48-53.

Servicio de Relaciones Públicas. 1976. "Nueva propuesta al I.N.P. sobre las urgencias de la 261enefi." Butlleti de l'Hospital de la Santa Creu i Sant Pau., 15: 1-2.

Servicio de Relaciones Públicas. 1979. "A nivel local. Puesta en marcha de la coordinación de las urgencias.” Butlletí de l'Hospital de la Santa Creu i Sant Pau., 43: 2.

Sitjes Creus, Antoni. 1962a. "El Centro de traumatologia del Hospital Cochin de Paris." Estudios sobre Hospitales y 261eneficència 9: 32-36.

Sitjes Creus, Antoni. 1962b. "Función 261eneficència del Hospital." Estudios sobre Hospitales y 261eneficència 12: 7-11.

Stewart, John. 2008. "The Political Economy of the British National Health Service, 1945-1975: Opportunities and Constraints?" Medical History 52(4): 453-470.

Soler Durall, Carles. 1967. Instrucciones permanentes del servicio de urgencias. Barcelona: Hospital de la Santa Creu i Sant Pau

Torre Eleizegui, Lino. 1963. "Acerca de la organización de las urgencias resultantes de catástrofes o desastres colectivos." Estudios sobre Hospitales y beneficencia 13: 21-24.

Torre Eleizegui, Lino. 1964. "La Organización de los servicios de urgencia en Lisboa." Estudios sobre Hospitales y beneficencia 18: 25-27.

Trabacchi, G. 1997. "Les urgences médico-judiciaires de l'Hôtel-Dieu ont 10 ans." Revue de l'infirmière 25: $12-16$.

Trunkey, Donald D. 2000. "History and Development of Trauma care in the United States." Clinical Orthopaedics and Related Research 374: 36-46. 


\section{Journal of Evolutionary Studies in Business}

Trunkey, Donald D. (2007). "The emerging crisis in trauma care: a history and definition of the problem." Clinical Neurosurgery 54: 200-205.

Varon, Joseph, and George L. Sternbach. 1991. "Cardiopulmonary resuscitation: Lessons from the past." Journal of Emergency Medicine 9(6): 503-507. doi: 10.1016/0736-4679(91)90224-4.

Vasilachis de Gialdino, Irene, coord., Aldo R. Ameigeiras, Lilia B. Chernobilsky, Verónica Giménez Béliveau, Fortunato Mallimaci, Nora Mendizábal, Guillermo Neiman, Germán Quaranta, and Jorge Soneira, 2006. Estrategias de investigación cualitativa. Barcelona: Editorial Gedisa.

Vila Gimeno, Carme. 2014. "El Servei d'urgències de l'Hospital de la Santa Creu i Sant Pau de Barcelona (1967-1986).” PhD disc., Universitat Autònoma de Barcelona.

Villamarin Vazquez, José Luis. 1971. “Organización Hospitalaria y planificación sanitaria en la U.R.S.S.” Estudios sobre Hospitales 47: 27-43.

Zoll, Paul M., Arthur J. Linenthal, William Gibson, Milton H. Paul, and Leona R. Norman. 1956. "Termination of ventricular fibrillation in man by externally applited electric countershock." New England Journal of Medicine 254: 727-732. doi: 10.1056/NEJM195604192541601.

This is an Open Access article distributed under the terms of the Creative Commons Attribution-Non-Commercial-No Derivatives License (http://creativecommons.org/licenses/by-nc-nd/4.0/), which permits non-comercial re-use and distribution, provided the original work is properly cited, and is not altered or transformed in any way. 